\title{
ЕФЕКТИВНІСТЬ ВИКОНАННЯ РЕНТГЕНОЛОГІЧНОГО ОБСТЕЖЕННЯ В ДІАГНОСТИЦІ ВНУТРІШНЬОСУГЛОБОВИХ М'ЯКОТКАНИННИХ УШКОДЖЕНЬ НА РАННІХ СТАДІЯХ КОКСАРТРОЗУ
}

\author{
๑В. Г. Луцишин ${ }^{2}$ А. В. Калашніков', В. М. Майко², О. В. Майко3 \\ ДУ «Інститут травматології та ортопедії НАМН України»' \\ Вінницька обласна клінічна лікарня ім. М. І. Пирогова² \\ Вінницький національний медичний університет ім. М. І. Пироговаз
}

РЕЗЮМЕ. Цікавим в науковому та практичному плані $\epsilon$ проведення аналізу даних рентгенологічного обстеження хворих з метою визначення патогномонічних рентгенологічних ознакокомплексів, які визначали ушкодження внутрішньосуглобових структур кульшового суглоба та які були підтверджені артроскопічно.

Мета дослідження - визначити патогномонічні рентгенологічні ознакокомплекси, які характеризують внутрішньосуглобові м'якотканинні ушкодження кульшового суглоба (ВУМЕКС). Було проведено обстеження 105 хворих з коксартрозом I-ІІ стадії з визначенням патогномонічних рентгеноознакокомплексів, що характеризують ВУМЕКС, яким проводили артроскопічне оперативне втручання на базі травматологічного відділення Вінницької обласної лікарні ім. М.І.Пирогова в період з 2006-2015 р.

Матеріали і методи. Для оцінки поширеності рентгенологічних ознак у хворих з ВУМЕКС та початковими стадіями коксартрозу і їх поєднанням був проведений частотний аналіз.

Результати. У обстежених хворих визначена низька частота поширеності рентгенологічних ознак, які характерні для ВУМЕКС при ранніх стадіях КА. До рентгенологічних ознак, що характерні для ріпсег-типу ФАК, з частотою $\geq 0,4$ зустрічалися такі: ознака заднього краю (posterior wall sing) $(0,47)$; кут Віберга менше $39^{\circ}(0,45)$; зменшення величини індексу екструзії $(0,40)$, ацетабулярний індекс менше $0(0,42)$ та поєднання ознак: ознака заднього краю (posterior wall sing) + кут Віберга менше $39^{\circ}(0,4)$. Серед рентгенологічних ознак, що характерні для сат-типу ФАК, з частотою $\geq 0,4$ зустрічалися такі: деформація проксимального відділу стегнової кістки за типом руків'я пістолета $(0,46)$; горизонтальне положення росткової зони $(0,45)$; ШДК менше $125^{\circ}(0,46)$, кут альфа більше $50^{\circ}(0,48)$; індекс офсету менше $0,18(0,40)$ та поєднання ознак: деформація проксимального відділу стегнової кістки за типом руків'я пістолета + кут альфа більше $50^{\circ}(0,42)$. У той же час достовірними вважали дані, що складали $\geq 0,60$.

Висновок. Жодну з визначених рентгенологічних ознак (ознакокомплекс) не можна вважати достовірною в діагностиці ФАК у обстежених хворих, що доводить доволі низьку діагностичну цінність рентгенологічного обстеження даної категорії хворих.

КлючОВІ СлОВА: діагностика; рентгенологічні ознаки; внутрішньосуглобові ушкодження; коксартроз.

Вступ. Патологія кульшового суглоба $\epsilon$ найчастішою причиною тимчасової втрати працездатності, а інвалідність, за даними різних авторів, складає до 37,6 \% від кількості всіх інвалідів з ураженнями опорно-рухової системи. За даними ВООЗ, поширеність коксартрозу (КА) має тенденцію до подальшого зростання, що призведе до ще негативніших медичних і соціальних наслідків $[1,2]$.

KA - це дистрофічний процес, для якого характерні локальна і прогресивна втрата гіалінового суглобового хряща з супутніми змінами в субхондральній кістці, розвиток крайових розростань (остеофітів) та потовщення проміжної кісткової пластинки (субхондральний склероз). Уражаються також структури м'яких тканин у суглобі й навколо нього, включаючи синовіальну оболонку, де можуть спостерігатися помірні запальні інфільтрати, а також м'язи і зв'язки, які стають слабкими [1-3]. Усе це свідчить про високу медичну та соціальну значимість КА, який не тільки значно погіршує якість життя хворого, а й при- зводить до великих соціально-економічних витрат суспільства [6].

КА належить до багатофакторних захворювань суглобів. Серед факторів ризику значне місце займають травми, запальні процеси та дисплазії кісткової та хрящової тканин, у 26 \% випадків причину виникнення дегенеративно-дистрофічного процесу встановити не вдається. Однією з можливих причин розвитку так званого «ідіопатичного» коксартрозу можуть бути недіагностовані внутрішньосуглобові ушкодження ділянки кульшового суглоба. На сьогодні близько 60 \% внутрішньосуглобових ушкоджень безпосередньо кульшового суглоба (КС) діагностують неправильно через відсутність на ранніх (дорентгенологічних) стадіях змін на рентгенограмах [7].

Внутрішньосуглобові ураження м'якотканинних елементів КС (ВУМЕКС) різноманітні - травматичні та дегенеративні пошкодження ацетабулярної губи, круглої зв'язки, хряща суглобових поверхонь головки стегнової кістки та вертлюгової 
Огляди літератури, оригінальні дослідження, погляд на проблему, ювілеї

западини, феморо-ацетабулярний імпінджмент, вільні тіла кульшового суглоба $[10,15]$.

На основі клінічних даних та променевої діагностики виділяють три механізми імпінжментсиндрому: cam - механізм («стегновий тип»), pincer - механізм («ацетабулярний тип») та змішаний тип $[11,13]$. При всіх типах синдрому найвиразніші патологічні зміни виявляють у суглобовій губі кульшового суглоба

Прийнято вважати, що діагностика травм та захворювань, які призводять до порушення функції КС, відносно проста $[9,14]$. Проте з цим можна погодитися лише у випадках виразних морфологічних змін субхондріальної кістки, коли процес руйнування суглобового хряща досяг значного ступеня і зміни у кістковій тканині компенсують навантаження суглобових поверхонь. При початкових ураженнях суглобового хряща, яке і характеризує I-ІІ стадії KА, артроскопія КС $\epsilon$ «золотим стандартом» $[8,12]$ діагностики і лікування, який дозволяє візуально оцінити не тільки структурнофункціональний стан внутрішньосуглобових структур, а й виявити взаємовідношення та їх поведінку під час рухів у суглобі.

Вважаємо цікавим в науковому та практичному плані проведення аналізу даних рентгенологічного обстеження хворих з метою визначення патогномонічних рентгенологічних ознакокомплексів, які визначали ушкодження внутрішньосуглобових структур КС та які були підтверджені артроскопічно.

Мета дослідження - визначити патогномонічні рентгенологічні ознакокомплекси, які характеризують внутрішньосуглобові м'якотканинні ушкодження кульшового суглоба.

Матеріал і методи дослідження. Було о6стежено 105 пацієнтів з остеоартрозом кульшового суглоба; у 75 хворих діагностували ідіопатичний КА, у 30 - посттравматичний КА.
Серед хворих було 42 жінки та 63 чоловіки у віці від 22 до 72 років (середній вік-42,21 10,99 років): з ідіопатичним КА - 33 жінки та 42 чоловіки у віці від 22 до 69 років (середній вік-42,97士10,74 років), з посттравматичним КА - 9 жінок та 21 чоло-

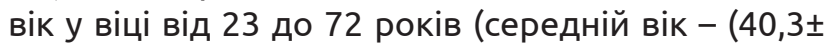
$11,34)$ років).

Метою обстеження було вивчення ефективності рентгенологічного методу дослідження, у порівнянні із артроскопією, в діагностиці ВУМЕКС у хворих на ранніх стадіях КА. Всім цим хворим проводили артроскопічне оперативне втручання на базі травматологічного відділення Вінницької обласної лікарні ім. М. І. Пирогова в період з 2006 по 2015 рік.

Серед всіх прооперованих хворих сат - тип імпінджмент-синдрому виявлено у 20 випадках, що склало 19 \% від загальної кількості хворих, pincer - тип - у 5 випадках (4,8 \%), змішаний тип-у 75 хворих (71,4\%), післятравматичне ізольоване ушкодження суглобової губи - у 3 випадках (2,9\%), вільні суглобові тіла - у 2 прооперованих хворих (1,9\%).

Для оцінки поширеності рентгенологічних ознак у хворих з ВУМЕКС та початковими стадіями коксартрозу і їх поєднання був проведений частотний аналіз. Відносну частоту (вірогідність) появи рентгенологічної ознаки та варіантів її поєднання визначали за формулою:

$$
\mathrm{P}=\frac{\begin{array}{c}
\text { кількість хворих з наявною рентгенологічною } \\
\text { ознакою (поєднання ознак) }
\end{array}}{\text { загальна кількість хворих }}[4,5] .
$$

Результати й обговорення. При частотному аналізі наявних рентгенологічних ознак та їх поєднання на ранніх стадіях коксартрозу при різних типах ФАК та інших ВУМЕКС були виявлені наступні числові показники, які представлені в таблиці 1.

Таблиця 1. Частотний аналіз рентгенологічних ознак та ознакокомплексів, що характеризують ВУМЕКС

\begin{tabular}{|c|c|c|}
\hline Рентгенологічні ознаки або їх поєднання & $\begin{array}{l}\text { Кількість } \\
\text { випадків }\end{array}$ & $\begin{array}{c}\text { Відносна } \\
\text { частота (p) }\end{array}$ \\
\hline 1 & 2 & 3 \\
\hline \multicolumn{3}{|l|}{ Pincer-тип ФАК } \\
\hline Coxa profunda & 24 & 0,30 \\
\hline Симптом cross-over & 28 & 0,35 \\
\hline Ознака заднього краю (posterior wall sing) & 38 & 0,47 \\
\hline Лінійне вдавлення на шийці стегнової кістки & 30 & 0,37 \\
\hline Кут Віберга менше $39^{\circ}$ & 36 & 0,45 \\
\hline Зменшення величини індексу екструзії & 32 & 0,40 \\
\hline Ацетабулярний індекс менше 0 & 34 & 0,42 \\
\hline Coxa profunda + симптом cross-over & 20 & 0,25 \\
\hline Coxa profunda + ознака заднього краю (posterior wall sing) & 24 & 0,30 \\
\hline Симптом cross-over + кут Віберга менше $39^{\circ}$ & 22 & 0,27 \\
\hline
\end{tabular}
при остеоартрозі кульшового суглоба 


\begin{tabular}{|c|c|c|}
\hline 1 & 2 & 3 \\
\hline Симптом cross-over + зменшення величини індексу екструзії & 20 & 0,25 \\
\hline Симптом cross-over + ацетабулярний індекс менше 0 & 21 & 0,26 \\
\hline Ознака заднього краю (posterior wall sing) + кут Віберга менше $39^{\circ}$ & 32 & 0,40 \\
\hline Ознака заднього краю (posterior wall sing) + зменшення величини індексу екструзії & 30 & 0,37 \\
\hline Ознака заднього краю (posterior wall sing) + ацетабулярний індекс менше 0 & 22 & 0,27 \\
\hline $\begin{array}{l}\text { Ознака заднього краю (posterior wall sing) + лінійне вдавлення на шийці стегнової } \\
\text { кістки }\end{array}$ & 23 & 0,28 \\
\hline Лінійне вдавлення на шийці стегнової кістки + кут Віберга менше $39^{\circ}$ & 18 & 0,22 \\
\hline $\begin{array}{l}\text { Лінійне вдавлення на шийці стегнової кістці + зменшення величини індексу } \\
\text { екструзї̈ }\end{array}$ & 17 & 0,21 \\
\hline Лінійне вдавлення на шийці стегнової кістки + Ацетабулярний індекс менше 0 & 19 & 0,23 \\
\hline $\begin{array}{l}\text { Симптом cross-over + лінійне вдавлення на шийці стегнової кістки + кут Віберга } \\
\text { менше } 39^{\circ}\end{array}$ & 15 & 0,19 \\
\hline $\begin{array}{l}\text { Симптом cross-over + лінійне вдавлення на шийці стегнової кістки + } \\
\text { ацетабулярний індекс менше } 0\end{array}$ & 14 & 0,17 \\
\hline $\begin{array}{l}\text { Симптом cross-over + лінійне вдавлення на шийці стегнової кістки + зменшення } \\
\text { величини індексу екструзії }\end{array}$ & 12 & 0,15 \\
\hline $\begin{array}{l}\text { Ознака заднього краю (posterior wall sing) + лінійне вдавлення на шийці стегнової } \\
\text { кістки + зменшення величини індексу екструзії }\end{array}$ & 12 & 0,15 \\
\hline $\begin{array}{l}\text { Ознака заднього краю (posterior wall sing) + лінійне вдавлення на шийці стегнової } \\
\text { кістки + кут Віберга менше } 39^{\circ}\end{array}$ & 13 & 0,16 \\
\hline $\begin{array}{l}\text { Ознака заднього краю (posterior wall sing) + лінійне вдавлення на шийці стегнової } \\
\text { кістки + ацетабулярний індекс менше } 0\end{array}$ & 12 & 0,15 \\
\hline $\begin{array}{l}\text { Симптом cross-over + лінійне вдавлення на шийці стегнової кістки + зменшення } \\
\text { величини індексу екструзії + кут Віберга менше } 39^{\circ}\end{array}$ & 10 & 0,12 \\
\hline $\begin{array}{l}\text { Симптом cross-over + лінійне вдавлення на шийці стегнової кістки + зменшення } \\
\text { величини індексу екструзії + ацетабулярний індекс менше } 0\end{array}$ & 10 & 0,12 \\
\hline $\begin{array}{l}\text { Ознака заднього краю (posterior wall sing) + лінійне вдавлення на шийці стегнової } \\
\text { кістки + зменшення величини індексу екструзії + кут Віберга менше } 39^{\circ}\end{array}$ & 9 & 0,11 \\
\hline \multicolumn{3}{|l|}{ Cam-тип ФАК } \\
\hline Деформація проксимального відділу стегнової кістки за типом руків'я пістолета & 46 & 0,48 \\
\hline Горизонтальне положення росткової зони & 38 & 0,40 \\
\hline Симптом канату, що звисає & 26 & 0,27 \\
\hline ШДК менше $125^{\circ}$ & 44 & 0,46 \\
\hline Кут альфа більше $50^{\circ}$ & 48 & 0,50 \\
\hline Індекс офсету менше 0,18 & 40 & 0,42 \\
\hline Ретроверсія проксимального відділу стегна & 24 & 0,25 \\
\hline $\begin{array}{l}\text { Деформація проксимального відділу стегнової кістки за типом руків'я пістолета + } \\
\text { горизонтальне положення росткової зони }\end{array}$ & 34 & 0,36 \\
\hline $\begin{array}{l}\text { Деформація проксимального відділу стегнової кістки за типом руків'я пістолета + } \\
\text { симптом канату, що звисає }\end{array}$ & 22 & 0,23 \\
\hline $\begin{array}{l}\text { Деформація проксимального відділу стегнової кістки за типом руків'я пістолета + } \\
\text { кут альфа більше } 50^{\circ}\end{array}$ & 40 & 0,42 \\
\hline $\begin{array}{l}\text { Деформація проксимального відділу стегнової кістки за типом руків'я пістолета + } \\
\text { індекс офсету менше } 0,18\end{array}$ & 36 & 0,38 \\
\hline $\begin{array}{l}\text { Деформація проксимального відділу стегнової кістки за типом руків'я пістолета + } \\
\text { ретроверсія проксимального відділу стегна }\end{array}$ & 19 & 0,20 \\
\hline Горизонтальне положення росткової зони + кут альфа більше 50 & 30 & 0,32 \\
\hline Горизонтальне положення росткової зони + індекс офсету менше 0,18 & 29 & 0,30 \\
\hline $\begin{array}{l}\text { Горизонтальне положення росткової зони + ретроверсія проксимального відділу } \\
\text { стегна }\end{array}$ & 20 & 0,21 \\
\hline ШДК менше $125^{\circ}+$ кут альфа більше $50^{\circ}$ & 32 & 0,34 \\
\hline ШДК менше $125^{\circ}$ + горизонтальне положення росткової зони & 26 & 0,27 \\
\hline
\end{tabular}




\begin{tabular}{|c|c|c|}
\hline 1 & 2 & 3 \\
\hline ШДК менше $125^{\circ}+$ індекс офсету менше 0,18 & 21 & 0,22 \\
\hline ШДК менше $125^{\circ}$ + ретроверсія проксимального відділу стегна & 19 & 0,20 \\
\hline Симптом канату що звисає + ШДК менше $125^{\circ}$ & 18 & 0,19 \\
\hline Симптом канату що звисає + кут альфа більше $50^{\circ}$ & 20 & 0,21 \\
\hline Симптом канату що звисає + ретроверсія проксимального відділу стегна & 16 & 0,17 \\
\hline Симптом канату що звисає + горизонтальне положення росткової зони & 19 & 0,20 \\
\hline $\begin{array}{l}\text { Деформація проксимального відділу стегнової кістки за типом руків'я пістолета + } \\
\text { кут альфа більше 50 + ретроверсія проксимального відділу стегна }\end{array}$ & 17 & 0,18 \\
\hline $\begin{array}{l}\text { Деформація проксимального відділу стегнової кістки за типом руків'я пістолета + } \\
\text { шДК менше } 125^{\circ}+\text { кут альфа більше } 50^{\circ}\end{array}$ & 24 & 0,25 \\
\hline $\begin{array}{l}\text { Деформація проксимального відділу стегнової кістки за типом руків'я пістолета + } \\
\text { ШДК менше } 125^{\circ}+\text { ретроверсія проксимального відділу стегна }\end{array}$ & 14 & 0,15 \\
\hline $\begin{array}{l}\text { Деформація проксимального відділу стегнової кістки за типом руків'я пістолета + } \\
\text { горизонтальне положення росткової зони + ШДК менше } 125^{\circ}\end{array}$ & 18 & 0,19 \\
\hline $\begin{array}{l}\text { Деформація проксимального відділу стегнової кістки за типом руків'я пістолета + } \\
\text { горизонтальне положення росткової зони + ретроверсія проксимального відділу } \\
\text { стегна }\end{array}$ & 13 & 0,14 \\
\hline $\begin{array}{l}\text { Горизонтальне положення росткової зони + ШДК менше } 125^{\circ}+\text { ретроверсія } \\
\text { проксимального відділу стегна }\end{array}$ & 12 & 0,13 \\
\hline Горизонтальне положення росткової зони + ШДК менше $125^{\circ}+$ кут альфа більше 50 & 14 & 0,15 \\
\hline $\begin{array}{l}\text { Горизонтальне положення росткової зони + ШДК менше } 125^{\circ}+\text { індекс офсету } \\
\text { менше } 0,18\end{array}$ & 13 & 0,14 \\
\hline $\begin{array}{l}\text { Деформація проксимального відділу стегнової кістки за типом руків'я пістолета + } \\
\text { горизонтальне положення росткової зони ШДК менше } 125^{\circ}+\text { ретроверсія } \\
\text { проксимального відділу стегна }\end{array}$ & 9 & 0,09 \\
\hline $\begin{array}{l}\text { Деформація проксимального відділу стегнової кістки за типом руків'я пістолета + } \\
\text { горизонтальне положення росткової зони ШДК менше } 125^{\circ}+\text { індекс офсету менше } \\
0,18\end{array}$ & 10 & 0,10 \\
\hline \multicolumn{3}{|l|}{ Посттравматичне ізольоване ушкодження суглобової губи } \\
\hline Субхондральні кісти в верхньолатеральній частині кульшової западини & 1 & 0,33 \\
\hline \multicolumn{3}{|l|}{ Вільні суглобові тіла } \\
\hline Кулеподібні або овальні тіла з чіткими контурами & 1 & 0,50 \\
\hline
\end{tabular}

Аналізуючи дані, представлені в таблиці 1, визначили низьку частоту поширеності рентгенологічних ознак, які характерні для ВУМЕКС при ранніх стадіях КА у обстежених хворих. До рентгенологічних ознак, що характерні для ріпсег-типу ФАК з частотою $\geq 0,4$ зустрічалися такі: ознака заднього краю (роsterior wall sing)(0,47); кут Віберга менше $39^{\circ}(0,45)$; зменшення величини індексу екструзії $(0,40)$, ацетабулярний індекс менше $0(0,42)$ та поєднання ознак: ознака заднього краю (posterior wall sing) + кут Віберга менше $39^{\circ}(0,4)$. Серед рентгенологічних ознак, що характерні для сат-типу ФАК з частотою $\geq 0,4$ зустрічалися такі: деформація проксимального відділу стегнової кістки за типом руків'я пістолета $(0,46)$; горизонтальне положення росткової зони $(0,45)$; ШДК менше $125^{\circ}(0,46)$, кут альфа більше $50^{\circ}(0,48)$; індекс офсету менше 0,18 $(0,40)$ та поєднання ознак: деформація проксимального відділу стегнової кістки за типом руків'я пістолета + кут альфа більше $50^{\circ}(0,42)$. Достовірними вважали дані, що складали $\geq 0,60$. Таким чи- ном, жодна з визначених рентгенологічних ознак (ознакокомплекс) не може вважатися достовірною в діагностиці ФАК у обстежених хворих, що доводить доволі низьку ефективну діагностичну цінність рентгенологічного обстеження даної категорії хворих.

Рентгенологічні ознаки посттравматичного ізольованого ушкодження суглобової губи визначали в 1 випадку, з частотою 0,33; вільні суглобові тіла (що містили солі кальцію) теж визначалися в 1 випадку, частота 0,50. Проведене обстеження доводить доволі обмежену можливість використання рентгенологічного обстеження у цієї категорії хворих (рентгенологічні ознаки ушкодження суглобової губи визначаються лише при її хронічній травматизації, вільні суглобові тіла визначаються, якщо є рентгеноконтрастними (мають в своєму складі солі кальцію).

Проведене статистичне дослідження доводить низьку ефективність використання рентгенологічного дослідження з метою діагностики 
Огляди літератури, оригінальні дослідження, погляд на проблему, ювілеї

ВУМЕКС при ранніх стадіях КА обстежених хворих Жодна з визначених рентгенологічних ознак не була статистично достовірною під час частотного аналізу. Рентгенологічне дослідження цієї категорії хворих повинно обов'язково доповнюватись визначенням клінічних тестів та іншими променевими методами діагностики (МРТ, КТ та інші).

Висновки. 1.Проведене статистичне дослідження доводить низьку ефективність використання рентгенологічного дослідження для діагностики внутрішньосуглобових уражень м'якотканинних елементів кульшового суглоба при ранніх стадіях коксартрозу у обстежених хворих. Жодна з визначених рентгенологічних ознак не була статистично достовірною за результатами частотного аналізу.
2. Рентгенологічне дослідження хворих повинно обов'язково доповнюватись клінічними тестами, а також іншими променевими методами діагностики (МРТ, КТ та інші).

Перспективи подальших досліджень. Подальші статистичні та клінічні дослідження з метою визначення об єктивних синдромокомплексів, що визначають ушкодження суглобових структур у хворих з ранніми стадіями остеоартрозу кульшового суглоба, сприятиме розробці діагностичного алгоритму з метою раннього профілактичного лікування та запобігання подальшому прогресуванню коксартрозу у цієї категорії хворих.

\section{ЛІТЕРАТУРА}

1. Бадокин В. В. Значение воспаления в развитии и течении остеоартроза / В. В. Бадокин // Здоров'я України. - 2010. - Т. 19 (248). - С. 26-28.

2. Берглезов М. А. Остеоартроз (этиология, патогенез) / М. А. Берглезов Т. М. Андреева // Вестник травматологии и ортопедии им. Н. Н. Приярова. - 2006. - № 4. С. 79-86.

3. Дмитриева Л. А. Роль цитокинов в патогенезе остеоартрозов (обзор литературы) / Л. А. Дмитриева // Бюлл. ВСНЦ СО РАМН. - 2007. - Т. 56 (4). - С. 165-169.

4. Лапач С. Н. Статистические методы в биологических исследованиях с использованием Excel / С. Н. Лапач, А. В. Чубенко, П. Н. Бабич. - К. : Морион, 2000. - 320 с.

5. Мінцер О. П. Інформаційні технології в охороні здоров'я і практичній медицині [у 10 кн.]. Оброблення клінічних і експериментальних даних у медицині : навч. посіб. / О. П. Мінцер, Ю. В. Вороненко, В. В. Власов. - К. : Вища школа, 2003. - Кн. 5. - 350 с.

6. Миронов С. П. Остеоартроз. Современное состояние проблемы (аналитический обзор) / С. П. Миронов, Н. П. Омельяненко, А. К. Орлецкий // Вестн. травматол. и ортопед. им. Н. Н. Приярова. - 2001. - № 2. - С. 96-99.

7. Byrd J. W. Prospective analysis of hip arthroscopy / J. W. Byrd, K. S. Jones // Arthroscopy. - 2000. - No. 2. P. 578-587.

8. Byrd W. T. Operative hip arthroscopy / B. W. Byrd. Stuttgart, Thilme, 2001. - 213 p.

\section{REFERENCES}

1. Badokin, V.V. (2010). Znacheniye vospaleniya v razvitii i techenii osteoartrozu [The importance of inflammation in the development and flow of osteoarthritis]. Zdorovia Ukrainy - Health of Ukraine, 19 (248), 26-28 [in Russian].

2. Berglezov, M.A., \& Andreyeva, T.M. (2006). Osteoartroz (etiologiya, patogenez) [Osteoarthrosis (etiology, pathogenesis)]. Vestnik travmatologii i ortopedii im. N. N. Priorova - N. N. Priorov Bulletin of Traumatology and Orthopedics, 4, $79-86$ [in Russian].

3. Dmitriyeva, L.A. (2007). Rol tsitokinov v patogeneze osteoartrozov (obzor literatury) [The role of cytokines in the pathogenesis of osteoarthrosis (literature review)] Byull. VSNTS SO RAMN - Bull. VSSC of the RAMS, 56 (4), 165-169 [in Russian].

4. Lapach, S.N., Chubenko, A.V, \& Babich, P.N. (2000). Statisticheskiye metody $v$ biologicheskikh issledovaniyakh $s$ ispolzovaniyem Excel [Statistical methods in biological research using Excel]. Kyiv: "Morion" [in Russian]. 
Огляди літератури, оригінальні дослідження, погляд на проблему, ювілеї

5. Mintser, O.P., Voronenko, Yu.V., \& Vlasov, V.V. (2003). Informatsiini tekhnolohii vokhoroni zdorovia i praktychnii medytsyni: [u 10 kn.]. Obroblennia klinichnykh i eksperimentalnykh danykh u medytsyni: navch. posib. [Information technologies in healthcare and practical medicine: [in 10 books]. Treatment of clinical and experimental data in medicine: Teaching manual, book]. Kyiv: Vyshcha shkola [in Ukrainian].

6. Mironov, S.P., Omelyanenko, N.P., \& Orletskiy, A.K. (2001). Osteoartroz: Sovremennoye sostoyaniye problemy (analiticheskiy obzor) [Osteoarthrosis: Current state of the problem (analytical review)]. Vestn. travmatol. i ortoped. im. N. N. Priyarova - N. N. Priyarov Bulletin of Traumatology and Orthopedics, 2, 96-99 [in Russian].

7. Byrd, J.W., \& Jones, K.S. (2000). Prospective analysis of hip arthroscopy. Arthroscopy, 2, 578-587.

8. Byrd, W.T. (2001). Operative hip arthroscopy. Stuttgart, Thilme, $213 \mathrm{p}$.

9. Dietrich, F., Ries, C., \& Eiermann, C. (2014). Complications in hip arthroscopy: necessity of supervision during the learning curve. Knee Surg. Sports Traumatol. Arthrosc., 22, 953-958.
10. Kelly, B.T., \& Buly, R.L. (2005). Hip arthroscopy update. J. Hss., 1, 40-48.

11. Stoller, D.W., Li, A.E., \& Lichtman, D.M. (2007). Magnetic resonance imaging in orthopedics and sports medicine. 3rd Edition Philladelphia: Lippincott William, 1049.

12. Mc Carthy, J.C., \& Lee, J.A. (2006). Hip arthroscopy: indications, outcomes, and complications. Instr. Course Lect., 55, 301-308.

13. James, S., Ali, K., \& Malara, F. (2006). MRI Findings of Femaroacetabular impingement. A. J. R. Am. J. Roentgtnol, 6 (187), 1412-1419.

14. Botser, I.B., Jr. Smith, T.W., \& Nasser, R. (2011). Open surgical dislocation versus arthroscopy for femoroacetabular impingement: a comparison of clinical outcomes. Arthroscopy, 27, 270-278.

15. Philippon, M.J., Briggs, K.K., \& Yen, Y.M. (2009). Outcomes following hip arthroscopy for femoroacetabular impingement with associated chondrolabral dysfunction: minimum two-year follow-up. J. Bone Joint. Surg Br., 91, 16-23.

\title{
ЭФФЕКТИВНОСТЬ ВЫПОЛНЕНИЯ РЕНТГЕНОЛОГИЧЕСКОГО ОБСЛЕДОВАНИЯ В ДИАГНОСТИКЕ ВНУТРИСУСТАВНЫХ МЯГКОТКАННЫХ ПОВРЕЖДЕНИЙ НА РАННИХ СТАДИЯХ КОКСАРТРОЗА
}

\author{
๑В. Г. Луцишин ${ }^{2}$, А. В. Калашников ${ }^{1}$, В. М. Майко², Е. В. Майко ${ }^{3}$

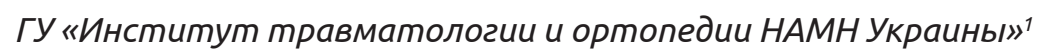 \\ Винницкая областная клиническая больница им. М. И. Пирогова ${ }^{2}$ \\ Винницкий национальный медицинский университет им. М. И. Пирогова
}

РЕЗЮМЕ. Интересным в научном и практическом плане является проведение анализа данных рентгенологического обследования больных с целью определения патогномоничных рентгенологических признакокомплексов, которые определяли повреждения внутрисуставных структур тазобедренного сустава и которые были подтверждены артроскопически.

Цель исследования - определить патогномоничные рентгенологические признакокомплексы, характеризующие внутрисуставные мягкотканные повреждения тазобедренного сустава (ВПМЕТС). Было проведено обследование 105 больных с коксартрозом I-ІІ стадии с определением патогномоничных рентгенопризнакокомплексов, характеризующие ВПМЕТС, которым проводилось артроскопическое оперативное вмешательство на базе травматологического отделения Винницкой областной больницы им. Н. И. Пирогова в период с 2006 до 2015 года.

Материал и методы. Для оценки распространенности рентгенологических признаков у больных с ВПМЕТС и начальными стадиями коксартроза и их сочетания был проведен частотной анализ.

Результаты. У обследованных больных определена низкая частота распространенности рентгенологических признаков, характерных для ВПМЕТС при ранних стадиях КА. К рентгенологическим признакам, которые характерны для ріпсег-типа ФАК, с частотой $\geq 0,4$ встречались такие: признак заднего края (рosterior wall sing) $(0,47)$ угол Виберга менее $39^{\circ}(0,45)$ уменьшение величины индекса экструзии $(0,40)$, ацетабулярный индекс меньше $0(0,42)$ и сочетание признаков: признак заднего края (рosterior wall sing) + угол Виберга менее $39^{\circ}(0,4)$. Среди рентгенологических признаков, характерных для сат-типа ФАК, с частотой $\geq 0,4$ встречались такие: деформация проксимального отдела бедренной кости по типу рукоятки пистолета $(0,46)$ горизонтальное положение ростковой зоны $(0,45)$ ШДК менее $125^{\circ}(0,46)$, угол альфа больше $50^{\circ}(0,48)$ индекс офсета менее $0,18(0,40)$ и сочетание признаков: деформация проксимального отдела бедренной кости по типу рукоятки пистолета + угол альфа больше $50^{\circ}(0,42)$. В то же время достоверными считали данные, которые составляли $\geq 0,60$.

Вывод. Ни один определенный рентгенологический признак (признакокомплекс) не может считаться достоверным в диагностике ФАК у обследованных больных, что доказывает довольно низкую эффективную диагностическую ценность рентгенологического обследования данной категории больных.

КЛЮЧЕВЫЕ СЛОВА: диагностика; рентгенологические признаки; внутрисуставные повреждения; коксартроз. 


\title{
Огляди літератури, оригінальні дослідження, погляд на проблему, ювілеї
}

\section{EFFICIENCY OF EXECUTION OF X-RAY GENETICAL EXAMINATION IN DIAGNOSTICS OF INTRAUTURE SOFT TREATMENT DAMAGE IN EARLY STAGES OF COXARPHROSIS}

\author{
๑V. G. Lutsishin², A. V. Kalashnikov', V. M. Maiko², E. V. Maiko ${ }^{3}$
}

Institute of Traumatology and Orthopedics of the NAMS of Ukraine ${ }^{1}$

M. Pyrohov Vinnytsia Regional Clinical Hospital ${ }^{2}$

M. Pyrohov Vinnytsia National Medical University ${ }^{3}$

SUMMARY. It is interesting in the scientific and practical terms to analyze the X-ray examination data of patients with the purpose of determining pathognomonic X-ray signs that set the damage of intraarticular structures of the hip joint and which were confirmed arthroscopically.

The aim of the study - to determine pathognomonic X-ray signs of characterizing intraarticular soft tissue injury of the hip joint (ISTIHJ). 105 patients with coxarthrosis of the I-II stage were examined with the definition of pathognomonic X-ray-indicative complexes, which characterize ISTIHJ, who underwent arthroscopic surgery on the basis of the Traumatology Department of M. Pyrohov Vinnytsia Regional Hospital in the period from 2006-2015.

Material and Methods. To assess the prevalence of radiologic signs in patients with ISTIHJ and the initial stages of coxarthrosis and their combination, a frequency analysis was performed. A low frequency of prevalence of X-ray signs characteristic for ISTIHJ at early stages of CA in the patients was determined. CA, to the X-ray signs that are typical for the pincer-type FAK with a frequency $\geq 0.4$, there were: a posterior wall sing $(0.47)$ a Viberg angle less than $39^{\circ}(0.45)$ a decrease in the value of the extrusion index (0.40), the acetabular index is less than $0(0.42)$ and a combination of signs: posterior wall sing + Viberg angle less than $39^{\circ}(0.4)$. Among the X-ray signs characteristic for the cam-type FAK with a frequency of $\geq 0.4$, there were: deformation of the proximal femur by the type of the pistol handle (0.46) horizontal position of the growth zone $(0.45)$ SDK less than $125^{\circ}(0.46)$, the alpha angle is greater than $50^{\circ}(0.48)$, the index of the offset is less than $0.18(0.40)$ and the combination of signs: deformation of the proximal femur by the type of the pistol grip + alpha angle is greater than $50^{\circ}(0,42)$. At the same time, reliable data were considered to be $\geq 0.60$.

Conclusion. No specific radiologic sign (indicia) can not be considered reliable in the diagnosis of FAK in the patients examined, proves the rather low effective diagnostic value of $\mathrm{X}$-ray examination of this category of patients.

KEY WORDS: diagnostics; $X$-ray signs; intraarticular lesions; coxarthrosis. 